\section{PENINGKATAN KEMAMPUAN AFEKTIF PESERTA DIDIK MELALUI MODEL VALUE CLARIFICATION TECHNIQUE PADA MATA PELAJARAN PKn di MI}

\author{
Ali Imron, Mohlisin \\ Program Studi Pendidikan Guru Madrasah Ibtidaiyah Universitas Wahid Hasyim \\ Semarang, Madrasah Ibtidaiyah Miftahul Huda Semarang \\ aliimron.aya@gmail.com, lisinkos@gmail.com
}

\begin{abstract}
Abstrak
Tujuan penelitian ini adalah untuk mengetahui: 1) pelaksanaan pembelajaran dengan model pembelajaran Value Clarification Technique di Kelas V MI Al-Mubarok Margolinduk Bonang Demak, 2) meningkatnya kemampuan afektif peserta didik dengan model pembelajaran Value Clarification Technique pada mata pelajaran PKn di kelas V MI Al-Mubarok Margolinduk Bonang Demak. Metode penelitian yang digunakan adalah Classroom Action Research. Subjek penelitiannya peserta didik kelas V MI Al-Mubarok Margolinduk Bonang Demak. Penelitian tindakan ini terdiri atas empat langkah: Planning; Acting; Observasing; Reflecting;. Metode pengumpulan datanya adalah observasi, skala sikap (non-tes), interview (wawancara), dan dokumentasi. Analisis data yang digunakan adalah deskriptif kualitatif, dengan teknik analisis data observasi aktivitas guru dan peserta didik selama pembelajaran. Setelah dilakukan penelitian diketahui bahwa: 1) pelaksanaan model pembelajaran $V C T$ di kelas $\mathrm{V}$ MI AlMubarok Margolinduk Bonang Dema terlaksana dengan baik. Aktivitas peserta didik melalui penerapan model pembelajaran $V C T$ juga mengalami peningkatan, yang paling menonjol adalah aktivitas di analisis dan presentasi hasil diskusi kelompok. Peserta didik dulunya pasif menjadi lebih aktif dan bersemangat mengikuti pembelajaran.
\end{abstract}

Kata Kunci: Kemampuan Afektif, Value Clarification Technique, Pendidikan Kewarganegaraan, Madrasah Ibtidaiyah.

\begin{abstract}
The aims of this study were to determine: 1) the implementation of learning using Value Clarification Technique in fifth grade students of MI Al-Mubarok Margolinduk Bonang Demak, 2) increasing the affective abilities of students using Value Clarification Technique on PKn subjects in fifth grade students of MI Al. -Mubarok Margolinduk Bonang Demak.

The research method used is Classroom Action Research. The research subjects were students of fifth grade students of MI Al-Mubarok Margolinduk Bonang Demak. This action research consists of four steps: Planning; Acting; Observing; Reflecting;. The data collection methods are observation, attitude scale (non-test), interview (interview), and documentation. The data analysis used is descriptive qualitative, with data analysis techniques observing the activities of teachers and students during learning. After conducting the research, it was found that: 1) the implementation of VCT learning model in class V MI Al-Mubarok Margolinduk Bonang Dema was carried out well. The activities of students through the application of VCT learning model also increased, the most prominent of which is activity in the result of analysis and presentation of group discussions. Students who used to be passive become more active and enthusiastic participating in learning.
\end{abstract}

Received:2021-6-8 Accepted::2021-6-20 Published:2021-6-23

Keywords: Affective Ability, Value Clarification Technique, PKn subject, Madrasah Ibtidaiyah 


\section{A. Pendahuluan}

Pendidikan memiliki tujuan untuk mengembangkan potensi peserta didik menjadi manusia yang beriman dan bertakwa kepada Tuhan Yang Maha Esa, berakhlak mulia, sehat, berilmu, cakap, kreatif, mandiri, dan menjadi warga negara yang demokratis serta bertanggung jawab. ${ }^{1}$ Dari tujuan tersebut, akhlak menjadi salah satu tujuan penting yang ingin dicapai. Hal ini sesuai dengan misi (risalah) Rasulullah SAW, yaitu untuk memperbaiki akhlak yang mulia sebagaimana sabdanya:

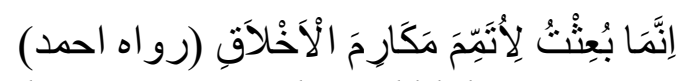

"Sesungguhnya aku diutus hanyalah untuk menyempurnakan akhlak yang mulia".2

Substansi yang terkandung dalam tujuan pendidikan nasional memiliki kandungan nilai-nilai karakter yang sangat kaya dan menjadi tantangan tersendiri bagi satuan pendidikan untuk menerjemahkan menjadi strategi pembelajaran yang secara efektif menumbukan nilai-nilai karakter yang dicita-citakan. ${ }^{3}$ Pendidikan nilai di madrasah memiliki pandangan dasar bermakna luas yang mendukung perkembangan pendidikan. Apa pun yang dilakukan madrasah, para guru menyisipkan makna nilai di dalamnya, termasuk bagaimana para guru, kepala madrasah, staf dan orang-orang dewasa lain memperlakukan para peserta didik. ${ }^{4}$

Seiring perubahan zaman yang begitu cepat, pada masalah-masalah moral yang muncul, dari masalah ketamakan dan ketidakjujuran hingga tindak kekerasan dan pengabaian diri, seperti penyalahgunaan narkoba dan tindakan bunuh diri. Perubahan-perubahan tersebut juga tidak hanya tergambar dari perilaku kekerasan yang dilakukan oleh remaja, tetapi juga dari berbagai bentuk ucapan dan tindakan tidak terpuji yang sudah mulai dilakukan anak-anak usia Sekolah Dasar. ${ }^{5}$

Pemerintah terus melakukan perbaikan peningkatan mutu pendidikan pada berbagai jenis dan jenjang. Namun faktanya masih terdapat rendahnya daya serap peserta didik. Hal ini tampak dari rerata hasil belajar peserta didik yang senantiasa

\footnotetext{
${ }^{1}$ Trianto, Mendesain Model Pembelajaran Inovatif-Progresif, Jakarta: Kencana, 2011, hlm. 1.

${ }^{2}$ Al-Imam Ahmad bin Hanbal, Musnad, Beirut: Darul Kutub al-Ilmiah, n.d., hlm. 504.

${ }^{3}$ Ace Suryadi, Pendidikan Indonesia Menuju 2025, Bandung: PT Remaja Rosdakarya, 2014, hlm.

${ }^{4}$ Thomas Lickona, Educating For Character, ed. Bumi Aksara, Jakarta, 2013, hlm.33.

${ }^{5}$ Lickona, 2013, hlm. 4-5.
} 97. 
masih sangat memprihatinkan. Prestasi ini tentunya merupakan hasil kondisi pembelajaran yang masih bersifat konvensional dan tidak menyentuh ranah dimensi peserta didik itu sendiri, yaitu bagaimana sebenarnya belajar itu (belajar untuk belajar). ${ }^{6}$

Proses pembelajaran hingga kini masih memberikan dominasi guru dan tidak memberikan akses bagi anak didik untuk berkembang secara mandiri melalui penemuan dalam proses berpikirnya. Di pihak lain secara empiris, berdasarkan hasil analisis penelitiian terhadap rendahnya hasil belajar peserta didik yang disebabkan dominannya proses pembelajaran konvensional. Pada pembelajaran ini suasana kelas cenderung teacher-centered, metodologi yang biasa dipakai oleh guru masih didominasi ekspositori dan pendekatannya masih bersifat tekstual sehingga siswa menjadi pasif. Masalah ini banyak dijumpai dalam kegiatan proses belajar mengajar di kelas, oleh karena itu, perlu menerapkan suatu model dan strategi belajar yang dapat membantu siswa untuk memahami materi ajar dan aplikasi serta relevansinya dalam kehidupan sehari-hari. ${ }^{7}$

Hasil observasi mengindikasikan, bahwa sebagian besar lulusan sekolah kurang mampu menyesuaikan diri dengan perubahan maupun perkembangan ilmu pengetahuan dan teknologi, sulit untuk bisa dilatih kembali, dan kurang bisa mengembangkan diri. Temuan tersebut tampaknya mengindikasi bahwa pembelajaran di sekolah belum banyak menyentuh atau mengembangkan kemampuan adaptasi peserta didik. ${ }^{8}$

Kondisi demikian juga terjadi dalam pelaksanaan pembelajaran PKn di kelas V MI Al-Mubarok Margolinduk Bonang Demak. Berdasarkan hasil wawancara yang peneliti lakukan pada wali kelas $\mathrm{V}$, selama mengajar peserta didik masih mengalami kesulitan dalam memahami nilai-nilai karakter yang terkandung dalam materi PKn. Berdasarkan hasil lembar pengamatan sebanyak 14 siswa dari jumlah keseluruhan 35 siswa yang belum menunjukkan sikap kejujuran, peduli sosial, bertanggung jawab dan semangat.

\footnotetext{
${ }^{6}$ Ali Imron, Peningkatan Hasil Belajar Menggunakan Metode Demonstrasi Pada Bidang Studi Al Qur'an Hadits MI, MAGISTRA 7, no. 1, 2016, hlm. 21.

${ }^{7}$ Trianto, Mendesain Model Pembelajaran Inovatif-Progresif, 2011, hlm. 4-5.

${ }^{8}$ Trianto, 2011, hlm.2.
} 
Mata pelajaran PKn merupakan mata pelajaran yang menitik beratkan pada ranah afektif atau sikap. Menurut Taniredja, Faridli, dan Harmianto, ranah afektif atau sikap tersebut terdiri dari wahana penanaman nilai, moral, dan norma-norma baku seperti rasa sosial, nasionalisme, bahkan sistem keyakinan. PKn seharusnya mampu mengeksplorasi internal side seseorang atau wilayah dalam diri seseorang, dan salah satu hasil dari internal side adalah sikap. ${ }^{9}$

Untuk itu, hendaknya pembelajaran PKn di kelas menjadi lebih bervariasi yang diharapkan dapat meningkatkan kemempuan afektif peserta didik dalam belajar. Pemilihan model pembelajaran yang tepat yang disesuaikan dengan karakteristik materi pelajaran. Menerapkan model pembelajaran yang inovatifprogresif, seperti Value Clarification Technique (VCT) bisa menjadi salah satu alternatifnya untuk meningkatkan kemampuan afektif peserta didik dalam memahami nilai kejujuran, tanggung jawab, peduli, dan rasa semangat siswa. ${ }^{10}$

Beberapa peneliti pernah melakukan tentang peningkatan kemampuan afektif atau sejenisnya antara lain: Ridlwan, "Meningkatkan Pengembangan Ranah Afektif Siswa dalam Pendidikan Agama Islam (PAI) Kelas III di SD Negeri Sukosewu Kecamatan Sukosewu Kabupaten Bojonegoro". 11 Muhammad Nurtanto dan Herminarto Sofyan, "Implementasi Problem-Based Learning (PBL) untuk Meningkatkan Hasil Belajar Kognitif, Psikomotor, dan Afektif Siswa di SMK ". ${ }^{2}$ Gustin Indra Setiana, "Penerapan Model Pembelajaran Value Clarification Technique (VCT) Permainan untuk Meningkatkan Hasil Belajar PKn Pada Siswa Kelas II SD Negeri Kemandungan 3 Kota Tegal". ${ }^{13}$ Persamaan penelitian adalah sama-sama memiliki tujuan meningkatkan kemampuan afektif peserta didik, sedangkan yang membedakan selain pada mata pelajaran adalah metode penelitian, hlm. 87 .

${ }^{9}$ Tukiran Taniredja, Model-Model Pembelajaran Inovatif Dan Efektif, Bandung: Alfabeta, 2015,

${ }^{10}$ Muhammad Fatturohman, Model-Model Pembelajaran Inovatif, Yogyakarta: Ar-Ruzz Media, 2015, hlm. 108 .

${ }^{11}$ Ridlwan, Meningkatkan Pengembangan Ranah Afektif Siswa Dalam Pendidikan Agama Islam (PAI) Kelas III Di SD Negeri Sukosewu Kec. Sukosewu Kab. Bojonegoro, Karya Pendidikan 2, no. 3 2016.

${ }^{12}$ Muhammad Nurtanto dan Herminarto Sofyan, Implementasi Problem-Based Learning Untuk Meningkatkan Hasil Belajar Kognitif, Psikomotor, Dan Afektif Siswa Di Smk," Pendidikan VOKASI 5, no. 3, 2015.

${ }^{13}$ Gustin Indra Setiana, Penerapan Model Pembelajaran Value Clarification Technique (VCT) Permainan Untuk Meningkatkan Hasil Belajar PKn Pada Siswa Kelas II SD Negeri Kemandungan 3 Kota Tegal, Semarang: Fakultas Pendidikan, 2012. 
Penelitian ini berbeda dengan penelitian yang terdahulu, penelitian ini menggunakan pendekatan PTK. Penelitian juga focus pada penerapkan model pembelajaran VCT pada mata pelajaran PKn kelas V MI dan juga terfokus pada peningkatkan kemampuan afektif peserta didik.

\section{B. Metode Penelitian}

Metode penelitian yang digunakan berupa Penelitian Tindakan Kelas (PTK) atau (Classroom Action Research), penelitian dilakukan terhadap perilaku dan tindakan yang muncul di dalam proses pembelajaran di kelas. Pada dasarnya penelitian tindakan diperlukan untuk mencermati dan memperbaiki sisi yang menjadi kekurangan dari sesuatu yang diteliti tersebut. ${ }^{14}$ PTK melibatkan peserta didik dan kolabolator sebagai mitra guru. ${ }^{15}$ Subjek penelitian ini adalah peserta didik kelas V MI Al-Mubarok Margolinduk Bonang Demak yang berjumlah 35 siswa. Lokasi penelitian di MI Al-Mubarok yang berada di jalan Wassalam No.7 RT 01 RW 03 Margolinduk Bonang Demak. Desain PTK ini disusun berdasarkan informasi yang lengkap dan kritis dengan memperhatikan penyusunan program, tindakan, observasi dan refleksi. ${ }^{16}$ Penelitian tindakan terdiri dari empat komponen pokok yaitu: 1. Perencanaan (Planning); 2. Tindakan (Acting); 3. Pengamatan (Observasing); dan 4. Refleksi (Reflecting) yang menunjukkan sebuah siklus sebagai salah satu ciri utama dari penelitian tindakan. ${ }^{17}$

Metode pengumpulan datanya adalah observasi, skala sikap (non-tes), interview (wawancara), dan dokumentasi. ${ }^{18}$ Analisis data menggunakan deskriptif kualitatif yang dinyatakan dalam kata-kata atau simbol. ${ }^{19}$ Adapun teknik analisis data pada penelitian ini adalah menggunakan analisis observasi setelah diperoleh data aktivitas guru selama pembelajaran dan aktivitas belajar siswa, kemudian data tersebut diolah dengan menggunakan rumus. ${ }^{20}$

14 Fitria Martanti, Penanaman Nilai-nilai Kejujuran Melalui Media Kantin Kejujuran di Pondok Pesantren Al-Hikmah Semarang, Jurnal Sosio Dialektika Volume 2, 2017. hlm. 49

${ }^{15}$ Euis Karwati dan Donni Juni Priansa, Manajemen Kelas (Classroom Management), Bandung: Alfabeta, 2014, hlm. 291-92.

${ }^{16}$ Suharsimi Arikunto, Prosedur Penelitian, Jakarta: PT Rineka Cipta, 2013, hlm. 303.

${ }^{17}$ Suharsimi Arikunto, 2013, hlm. 131.

${ }^{18}$ Sugiyono, Metode Penelitian Pendidikan, Bandung: Alfabeta, 2015, hlm. 172.

${ }^{19}$ Suharsimi Arikunto, Prosedur Penelitian, 2013, hlm. 282.

${ }^{20}$ Titik Indarti, Penelitian Tindakan Kelas (PTK) Dan Penulisan Ilmiah, Surabaya: FBS UNESA, 2008, hlm. 26. 
Ali Imron

$$
\mathrm{P}=\frac{f}{N} 100 \%
$$

Ket:

$\mathrm{P}=$ Persentase frekuensi kejadian yang muncul

Page | $95 \quad \mathrm{f}=$ Banyaknya aktivitas guru/siswa yang muncul

$\mathrm{N}=$ Jumlah aktivitas keseluruhan

Tolak ukur keberhasilan pelaksanaan penelitian tindakan kelas ini dapat dilihat dari: 1) aktivitas belajar peserta didik dinyatakan berhasil apabila prosentase aktivitas belajarnya mencapai $\geq 80 \%$ dari jumlah peserta didik yang telah aktif mengikuti pembelajaran PKn. 2) Kemampuan afektif peserta didik dinyatakan berhasil apabila prosentase kemampuan afektifnya mencapai $\geq 80 \%$ dari jumlah peserta didik yang mengikuti pembelajaran PKn.

\section{Hasil dan Pembahasan}

a. Pengertian Model Pembelajaran Value Clarification Technique

Model pembelajaran Value Clarification Technique (VCT) merupakan sebuah cara menanamkan dan mengungkapkan nilai-nilai tertentu dari peserta didik. ${ }^{21}$ Adapun menurut Bahar VCT merupakan suatu model pengklarifikasian sikap yang sesuai dengan tuntutan perkembangan pembelajaran PKn masa sekarang. ${ }^{22}$ Sependapat dengan Sanjaya dikutip Tukiran, bahwa VCT dapat membantu siswa mencari dan menentukan suatu nilai yang dianggapnya baik dalam menghadapi suatu persoalan melalui proses menganalisis nilai yang sudah ada dan tertanam dalam diri siswa. ${ }^{23}$

Berdasarkan pendapat di atas, dapat disimpulkan bahwa Model Pembelajaran VCT merupakan teknik pendidikan nilai di mana peserta didik dilatih untuk menemukan, memilih, menganalisis, membantu peserta didik dalam mencari dan memutuskan sikap sendiri mengenai nilai-nilai hidup yang ingin diperjuangkannya.

21 S. Ichas Hamid Al-lamri dan Tuti Istianti Ichas, Pengembangan Pendidikan Nilai Dalam Pembelajaran Pengetahuan Sosial Di Sekolah Dasar, Jakarta: Dirjendikti, 2006, hlm. 87.

${ }^{22}$ Helbi Akbar Martoni, Andrizal, Penerapan Teknik Mengklarifikasi Nilai (Value Clarification Technique) Untuk Meningkatkan Pemahaman Belajar Siswa Pada Mata Pelajaran Pendidikan Agama Islam, J-PAI: Jurnal Pendidikan Agama Islam 5, no. 2, 2019, hlm. 95.

${ }^{23}$ Taniredja, Model-Model Pembelajaran Inovatif Dan Efektif, 2015. hlm. 87-88. 
b. Karakteristik Value Clarification Technique

Karakteristik VCT adalah proses penanaman nilai yang dilakukan melalui proses analisis nilai yang sudah ada sebelumnya dalam diri peserta didik kemudian menyelaraskan dengan nilai-nilai baru yang hendak ditanamkan. $^{24}$ VCT membina siswa mengenai cara menilai, mengambil keputusan terhadap suatu nilai umum untuk kemudian dilaksanakannya sebagai warga masyarakat. ${ }^{25}$

Jadi, dengan karakteristik VCT ini, siswa akan terlibat secara aktif dalam mengembangkan pemahaman dan pengenalannya terhadap nilai-nilai pribadi, mengambil keputusan dan bertindak sesuai dengan keputusan pribadi.

c. Tujuan Penggunaan Value Clarification Technique dalam Pembelajaran PKn

Menurut Taniredja, Faridli, dan Harmianto tujuan menggunakan model VCT dalam pembelajaran PKn yaitu:

1) mengetahui dan mengukur tingkat kesadaran siswa tentang suatu nilai;

2) menanamkan kesadaran siswa tentang nilai-nilai yang dimiliki;

3) menanamkan nilai-nilai tertentu kepada siswa melalui cara yang rasional (logis) dan diterima siswa;

4) melatih siswa dalam menerima dan menilai nilai dirinya dan posisi nilai orang lain. ${ }^{26}$

Maksud dari tujuan $V C T$ di atas adalah agar peserta didik membangun nilai yang menurut anggapan baik, yang pada gilirannya nilai-nilai tersebut akan mewarnai perilakunya dalam kehidupan sehari-hari di masyarakat.

d. Langkah-langkah Pelaksanaan Model Pembelajaran VCT

Pelaksanaan Model Pembelajaran VCT dalam Taniredja, Faridli, dan Harmianto adalah:

1) Kebebasan memilih, yang terdiri dari 3 tahap pembelajaran yaitu: (1) memilih secara bebas, artinya kesempatan untuk menentukan pilihan yang menurutnya baik karena nilai yang dipaksakan tidak akan menjadi miliknya secara penuh; (2) memilih dari beberapa alternatif, artinya untuk

${ }^{24}$ Taniredja, 2015, hlm. 88.

25 Eny Sukmawati dan Ganes Gunansyah, Upaya Meningkatkan Hasil Belajar IPS Melalui Penerapan Model Pembelajaran Value Clarification Technique (VCT), Jurnal Penelitian Pendidikan Guru Sekolah Dasar 2, no. 3, 2014.

${ }^{26}$ Taniredja, Model-Model Pembelajaran Inovatif Dan Efektif, 2015, hlm. 88. 
menentukan pilihan dari beberapa alternatif pilihan secara bebas; serta (3) memilih setelah dilakukan analisis pertimbangan konsekuensi yang akan timbul sebagai akibat pilihannya.

2) Menghargai, terdiri dari 2 tahap pembelajaran, yaitu: (1) adanya perasaan senang dan bangga dengan nilai yang menjadi pilihannya, sehingga nilai tersebut akan menjadi bagian dari dirinya; (2) menegaskan nilai yang sudah menjadi bagian integral dalam dirinya di depan umum, artinya jika kita menganggap nilai itu suatu pilihan, maka kita akan berani dengan penuh kesadaran untuk menunjukkannya di depan orang lain.

3) Berbuat, terdapat 2 tahap pembelajaran, yaitu: (1) kemauan dan kemampuan untuk mencoba melaksanakannya; (2) mengulangi perilaku sesuai dengan nilai pilihannya, artinya nilai yang menjadi pilihan itu harus tercermin dalam kehidupannya sehari-hari. ${ }^{27}$

Jika dilihat dari tahap-tahap pelaksanaannya, pembelajaran VCT sebetulnya menekankan bagaimana seseorang membangun nilai yang dianggapnya baik untuk diaplikasikan dalam kehidupan sehari-hari.

e. Prinsip-prinsip Model Pembelajaran VCT

Ada lima prinsip yang harus diperhatikan dalam menerapkan model pembelajaran $V C T$, antara lain:

1) Penanaman nilai dan pengubahan sikap dipengaruhi banyak faktor antara lain faktor diri; kepekaan emosi, intelektual dan faktor lingkungan; norma nilai masyarakat, sistem pendidikan, lingkungan keluarga dan lingkungan bermain.

2) Sikap dan perubahan sikap dipengaruhi oleh stimulus yang diterima siswa dan kekuatan nilai yang telah tertanam atau dimiliki pada diri siswa.

3) Nilai, moral dan norma dipengaruhi oleh faktor perkembangan, sehingga guru harus mempertimbangkan tingkat perkembangan moral (moral development) dari setiap siswa. Tingkat perkembangan moral untuk siswa dipengaruhi oleh usia dan pengaruh lingkungan terutama lingkungan sosial.

\footnotetext{
${ }^{27}$ Taniredja, Model-Model Pembelajaran Inovatif Dan Efektif, 2015, hlm.89-90.
} 
4) Pengubahan sikap dan nilai memerlukan keterampilan mengklarifikasi nilai/sikap secara rasional sehingga dalam diri siswa muncul kesadaran diri bukan karena rasa kewajiban bersikap tertentu atau berbuat tertentu.

5) Pengubahan nilai memerlukan keterbukaan, karena itu pembelajaran PKn melalui VCT menuntut keterbukaan antara guru dengan siswa. ${ }^{28}$

Jadi, dengan prinsip-prinsip di atas, dalam pelaksanaan model VCT dapat berjalan dengan efektif, yaitu memperlibatkan siswa secara aktif dalam proses pembelajaran.

f. Bentuk-bentuk Model Pembelajaran VCT

Bentuk-bentuk model pembelajaran VCT menurut Djahiri, sebagaimana yang dikutip oleh Taniredja, Faridli, dan Harmianto menyebutkan bahwa terdapat lima bentuk VCT antara lain.

1) VCT dengan menganalisa suatu kasus yang kontroversial, suatu cerita yang dilematis, mengomentari kliping, membuat laporan dan kemudian dianalisa bersama.

2) VCT dengan menggunakan matrik. Jenis VCT ini meliputi; daftar baikburuk, daftar tingkat urutan, daftar skala prioritas, daftar gejala kontinum, daftar penilaian diri sendiri, daftar membaca perkiraan orang lain tentang diri kita, dan perisai.

3) VCT dengan menggunakan kartu keyakinan, kartu sederhana ini berisikan; pokok masalah, dasar pemikiran positif negatif dan pemecahan pendapat siswa yang kemudian diolah dengan analisa yang melibatkan sikap siswa terhadap masalah tersebut.

4) VCT melalui teknik wawancara; cara ini melatih keberanian siswa dan mampu mengklarifikasi pandangannya kepada lawan bicara dan menilai secara baik, jelas dan sistematis.

5) VCT dengan teknik inkuiri nilai dengan pertanyaan yang random, dengan cara ini siswa berlatih berpikir kritis, analistis, rasa ingin tahu dan sekaligus mampu merumuskan berbagai hipotesa/asumsi, yang berusa

${ }^{28}$ Taniredja, 2015, hlm.89. 
mengungkap suatu nilai atau sistem nilai yang ada atau dianut, atau yang menyimpang. ${ }^{29}$

Jadi, dari sekian banyaknya bentuk-bentuk VCT di atas, diharapkan dapat mengambil salah satu bentuk yang bisa menyesuaikan karakteristik dari isi materi yang diajarkan dengan kondisi siswa saat ini.

g. Pelaksanaan Pembelajaran dengan Model Pembelajaran Value Clarification Technique di Kelas V MI Al-Mubarok Margolinduk Bonang Demak

Pembelajaran PKn MI Al-Mubarok Margolinduk Bonang Demak dilaksanakan mulai dari pra siklus. Pra siklus digunakan untuk mengetahui sejauh mana guru mampu dalam mengajar, semangat dan kemampuan peserta didik, penggunaan model VCT dalam mata pelajaran PKn di MI Al-Mubarok. Selama proses pembelajaran tahap pra siklus, keterlibatan peserta didik masih pasif, mereka hanya duduk dan mendengarkan guru yang sedang ceramah. Akibatnya, potensi peserta didik tidak berkembang. Pada pelaksanaan siklus I, masih menunjukkan beberapa kelemahan yang menyebabkan belum sepenuhnya berhasil. Pada pelaksanaan proses pembelajaran siklus 2 lebih ditingkatkan kemampuan afektif peserta didik dalam memahami nilai kejujuran, tanggung jawab, peduli, dan semangat. Pada siklus 2 guru melaksanakan perbaikan pengajaran untuk menyelesaikan kendala yang ada pada siklus I dengan melihat refleksi pada siklus I.

Hasil skala sikap yang diperoleh peserta didik kelas V dari pra siklus diketahui prosentase kemampuan afektifnya dalam memahami nilai kejujuran, tanggung jawab, peduli, dan semangat mencapai 62\%, 62\%, 61\%, dan 61\% dengan kategori “cukup". Hal ini keberhasilan penanaman kesadaran mereka akan nilai kejujuran, tanggung jawab, peduli, dan semangat masih rendah. Karena belum mencapai tingkat keberhasilan penelitian yaitu $80 \%$. Sementara hasil observasi aktivitas peserta didik pada tahap pra siklus sebesar 59\% dengan kategori "cukup". Masih belum maksimalnya nilai peserta didik dalam pembelajaran pada tahap pra siklus ini adanya faktor dari diri peserta didik dan dari luar peserta didik yang dapat berupa model pembelajaran guru yang kurang menyenangkan bagi peserta didik. Untuk itu peneliti mengadakan perbaikan pembelajaran melalui penerapan model VCT pada siklus I.

\footnotetext{
${ }^{29}$ Taniredja, 2015, hlm. 90-91.
} 
Adapun hasil skala sikap (kemampuan afektif peserta didik dalam memahami nilai kejujuran, tanggung jawab, peduli, dan semangat) pada siklus I adalah: $72 \%$, 73\%, 75\%, dan 73\% dengan kategori "baik". Meskipun demikian, masih banyak peserta didik yang belum mampu memahami nilai kejujuran, tanggung jawab, peduli, dan semangat. Hal ini belum mencapai indikator keberhasilan penelitian yang telah ditentukan yaitu $80 \%$. Sementara hasil observasi aktivitas peserta didik pada siklus I mencapai peningkatan klasikal sebesar 68\% dengan kategori "baik". Hal ini disebabkan karena masih baru dan asing terhadap model pembelajaran VCT oleh karena itu perlu diadakan siklus 2.

Sedangkan hasil skala sikap (kemampuan afektif peserta didik dalam memahami nilai kejujuran, tanggung jawab, peduli, dan semangat) pada siklus 2 menunjukkan peningkatan yaitu sebesar $88 \%$ dengan kategori "sangat baik". Sementara hasil skala sikap yang diperoleh peserta didik telah mengalami peningkatan kemampuan afektif siswa dalam memahami nilai kejujuran, tanggung jawab peduli, dan semangat yakni sebesar 88\%, 89\%, 88\%, dan 88\% dengan kategori "sangat baik". Pencapaian prosentase ini lebih dari kriteria keberhasilan penelitian yaitu $80 \%$. Hal ini kemampuan afekif peserta didik dalam memahami nilai kejujuran, tanggung jawab, peduli, dan semangat sudah mencapai tingkat keberhasilan setelah mengikuti pembelajaran PKn dengan menggunakan model pembelajaran VCT.

Jadi secara keseluruhan pembelajaran Pendidikan Kewarganegaraan (PKn) dengan materi tentang menaati Peraturan Perundang-undangan yang berlaku di Indonesia dengan nilai kejujuran, bertanggung jawab, peduli, dan semangat sosial dengan penerapan model VCT sudah dapat meningkatkan kemampuan afektif peserta didik dalam memahami nilai kejujuran, bertanggung jawab, peduli, dan semangat. Selanjutnya peneliti menganggap penelitian ini sudah cukup karena peserta didik sudah mengalami peningkatan dalam pembelajaran khususnya pada siklus 2 .

h. Dampak penerapan model pembelajaran Value Clarification Technique terhadap kemampuan afektif peserta didik pada mata pelajaran PKn kelas V MI AlMubarok Margolinduk Bonang Demak

Perkembangan yang diperoleh dalam aktivitas peserta didik, dan skala sikap (kemampuan afektif peserta didik dalam memahami nilai kejujuran, tanggung jawab, peduli, dan semangat). 


\section{Ali Imron}

Peningkatan Aktivitas peserta didik, dengan menerapkan model pembelajaran $V C T$, siswa diberikan kesempatan untuk terlibat aktif dalam pembelajaran, karena sasaran utama kegiatan adalah keterlibatan siswa secara maksimal dalam proses belajar mengajar.

\section{Tabel 1}

Perbandingan Prosentase Aktivitas Siswa dalam Pembelajaran pada Pra Siklus, Siklus I, dan Siklus 2

\begin{tabular}{|l|l|l|l|}
\hline N0. & \multicolumn{1}{|c|}{ Pelaksanaan Siklus } & Prosentase (\%) & \multicolumn{1}{|c|}{ Kategori } \\
\hline 1. & Pra Siklus & $59 \%$ & Cukup \\
\hline 2. & Siklus I & $68 \%$ & Baik \\
\hline 3. & Siklus 2 & $88 \%$ & Sangat Baik \\
\hline
\end{tabular}

Adanya peningkatan aktivitas siswa dalam pembelajaran yang terjadi pada setiap siklusnya juga dapat disajikan dengan diagram berikut ini:

\section{Digram 1}

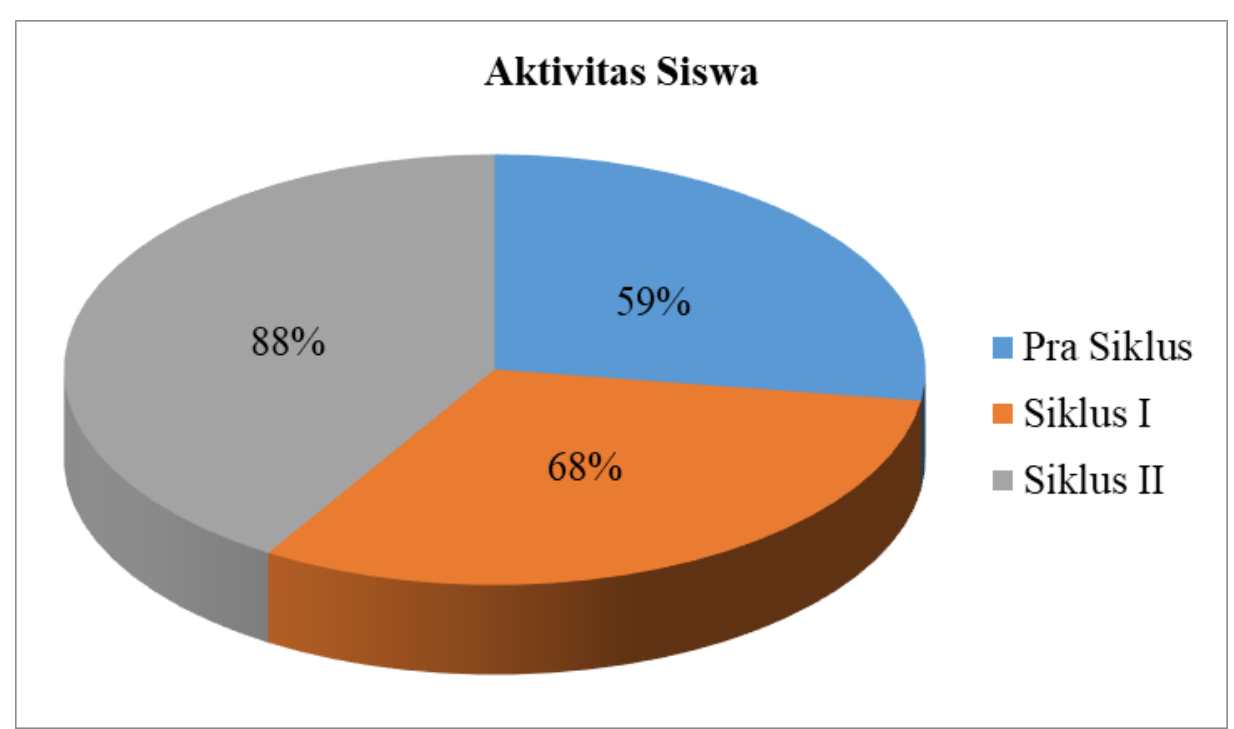

Aktivitas siswa pada pra siklus hanya mencapai 59,18\% dan dikategorikan “cukup". Dalam meningkatkan kemampuan belajar tersebut pembelajaran harus dikemas semenarik mungkin, penggunaan model yang tepat, memberikan inovasi baru dalam proses belajar mengajar agar memberikan kesan menyenangkan dan menambah keaktifan siswa di dalam kelas saat pembelajaran berlangsung. Hal ini sejalan dengan apa yang dikemukakan oleh Eggen dan Kauchak sebagaimana yang dikutip oleh Trianto bahwa model pembelajaran memberikan kerangka dan arah bagi guru untuk mengajar. ${ }^{30}$ Untuk itu perlu adanya model baru yang bisa mengajak siswa

\footnotetext{
${ }^{30}$ Trianto, Mendesain Model Pembelajaran Inovatif-Progresif, 2011, hlm.22.
} 
aktif di dalam kelas saat pembelajaran yakni dengan menggunakan model pembelajaran $V C T$.

Aktivitas siswa pada siklus I ini belum sepenuhnya maksimal karena siswa belum terbiasa dengan model pembelajaran VCT yang diterapkan. Dalam pelaksanaan pembelajaran pada siklus I aktivitas siswa mengalami peningkatan sebesar $68 \%$ dan dikategorikan "baik". Aktivitas siswa berpartsipasi aktif dalam pembelajaran, yaitu siswa aktif bertanya dan mengemukakan pendapat pada saat proses pembelajaran berlangsung. Hal tersebut sesuai dengan pendapat Djahiri, sebagaimana yang dikutip oleh Taniredja mengemukakan bahwa salah satu keunggulan VCT yaitu mampu mengundang, melibatkan, membina dan mengembangkan potensi diri siswa terutama mengembangkan potensi sikap. ${ }^{31}$

Dalam pelaksanaan pembelajaran pada siklus I ada beberapa aktivitas siswa yang kurang maksimal antara lain masih kesusahan dalam pengerjaan LKS karena ilustrasi cerita terlalu banyak, dalam mengerjakan skala sikap masih banyak yang kebingungan, dan menentukan posisi/pilihan/pendapat serta kendala yang dialami yaitu mengalami kesulitan mengendalikan diri dalam kelompok, serta masih ada beberapa yang kurang berinteraksi dengan kelompok. Oleh karena itu, pada siklus I ini perlu diperbaiki dan lebih memaksimalkan pada siklus 2 .

Dalam pelaksanaan pembelajaran pada siklus 2 aktivitas siswa mengalami peningkatan sebesar $88 \%$ dan dikategorikan "sangat baik" yaitu mampu menentukan posisi/pilihan/pendapat dengan cara beberapa siswa mengemukakan pendapat individual terkait permasalahan yang ditentukan, selanjutnya siswa mengemukakan alasan atas pendapatnya. Hal ini sesuai dengan pendapat Taniredja, salah satu tujuan $V C T$ yaitu melatih siswa dalam menerima menilai nilai dirinya dan posisi nilai orang lain, menerima serta mengambil keputusan terhadap sesuatu persoalan yang berhubungan dengan pergaulannya dan kehidupan sebari-hari. ${ }^{32}$ Pendapat tersebut telah dibuktikan dengan penelitian yang dilakukan oleh Haris dan Gunansyah, bahwa aktivitas siswa selama pembelajaran dengan menggunakan model $V C T$ telah

\footnotetext{
${ }^{31}$ Taniredja, Model-Model Pembelajaran Inovatif Dan Efektif, 2015, hlm.91.

${ }^{32}$ Et.all Tukiran Taniredja, Model-Model Pembelajaran Inovatif Dan Efektif, Bandung: Alfabeta, 2015, hlm. 88 .
} 


\section{Ali Imron}

terlaksana dengan baik dalam menemukan nilai dan mengklarifikasi sikap diri yang dilakukan oleh siswa. ${ }^{33}$

Peningkatan skala sikap (kemampuan afektif siswa dalam memahami nilai kejujuran, tanggung jawab, peduli, dan semangat). Penelitian ini ditujukan untuk meningkatkan kemampuan afektif siswa dengan nilai kejujuran, tanggung jawab, peduli, dan semangat pada materi Menaati Peraturan Perundang-undangan yang berlaku di Indonesia. Sebelum dilaksanakan pembelajaran dengan menggunakan model VCT telah dilaksanakan observasi pra siklus, pada tahap ini kemampuan afektif siswa dalam memahami nilai kejujuran, tanggung jawab peduli, dan semangat masing-masing mencapai skor 62\%, 62\%, 61\%, dan 61\% dengan kategori "cukup" yang berarti belum memenuhi indikator keberhasilan. Kendala yang dialami pointpoint pernyataan dan bahasa yang digunakan dalam skala sikap masih membingungkan, serta petunjuk yang diberikan dalam skala sikap kurang jelas. Upaya perbaikan yang dilakukan yaitu dengan memperbaiki point-point pernyataan dalam skala sikap menjadi lebih mudah dan petunjuk yang ditulis dalam skala sikap lebih diperjelas.

Setelah dilaksanakan pembelajaran dengan menggunakan model pembelajaran VCT dan dilaksanakan observasi siklus I, kemampuan afektif siswa dalam memahami nilai kejujuran, tanggung jawab, peduli, dan semangat mengalami peningkatan masing-masing mencapai skor $72 \%, 73 \%, 75 \%$, dan $73 \%$ dengan kategori "baik" yang berarti masih belum mencapai indikator keberhasilan yang ditentukan dalam penelitian. Dalam pelaksanaannya terdapat kendala yang dialami yaitu point pernyataan masih ada yang membingungkan. Upaya perbaikan tetap dilakukan oleh peneliti dengan membenahi point-point pernyataan dalam skala sikap sehingga menjadi lebih mudah dan dapat dengan mudah dikerjakan oleh siswa.

Dengan pelaksanaan upaya perbaikan tersebut, didapatkan hasil peningkatan skala sikap ditentukan dikarenakan point-point pernyataan yang terdapat pada lembar penilaian skala sikap (kemampuan afektif siswa dalam memahami nilai kejujuran, tanggung jawab, peduli, dan semangat) pada siklus 2 yakni masing-masing mencapai

${ }^{33}$ Fairizah Haris, Penerapan Model Pembelajaran Vct (Value Clarification Technique) Untuk Meningkatkan Kesadaran Nilai Menghargai Jasa Pahlawan Pada Siswa Sekolah Dasar, Jurnal Penelitian Pendidikan Guru Sekolah Dasar 1, no. 2, 2013. 
skor sebesar $88 \%, 89 \%, 88 \%$, dan $88 \%$ dengan kategori "sangat baik" serta telah memenuhi indikator keberhasilan penelitian.

Di bawah ini akan dilihatkan sebuah tabel tentang perbandingan hasil prosentase kemampuan afektif siswa dalam pembelajaran tersebut pada setiap siklusnya:

Tabel 2

Perbandingan Hasil Prosentase Kemampuan Afektif Siswa Pada Tahap Pra Siklus, Siklus I, dan Siklus 2

\begin{tabular}{|c|l|c|c|c|c|}
\hline \multirow{2}{*}{ No. } & Pelaksanaan & \multicolumn{4}{|c|}{ Prosentase Kemampuan Afektif Siswa (\%) } \\
\cline { 3 - 6 } & Siklus & Jujur & Tanggung Jawab & Peduli & Semangat \\
\hline 1. & Pra Siklus & $62 \%$ & $62 \%$ & $61 \%$ & $61 \%$ \\
\hline 2. & Siklus I & $72 \%$ & $73 \%$ & $75 \%$ & $73 \%$ \\
\hline 3. & Siklus 2 & $88 \%$ & $89 \%$ & $88 \%$ & $88 \%$ \\
\hline
\end{tabular}

Peningkatan ini dapat dilihat juga dari diagram hasil prosentase kemampuan afektif siswa pra siklus, siklus I, dan siklus 2

Diagram 2

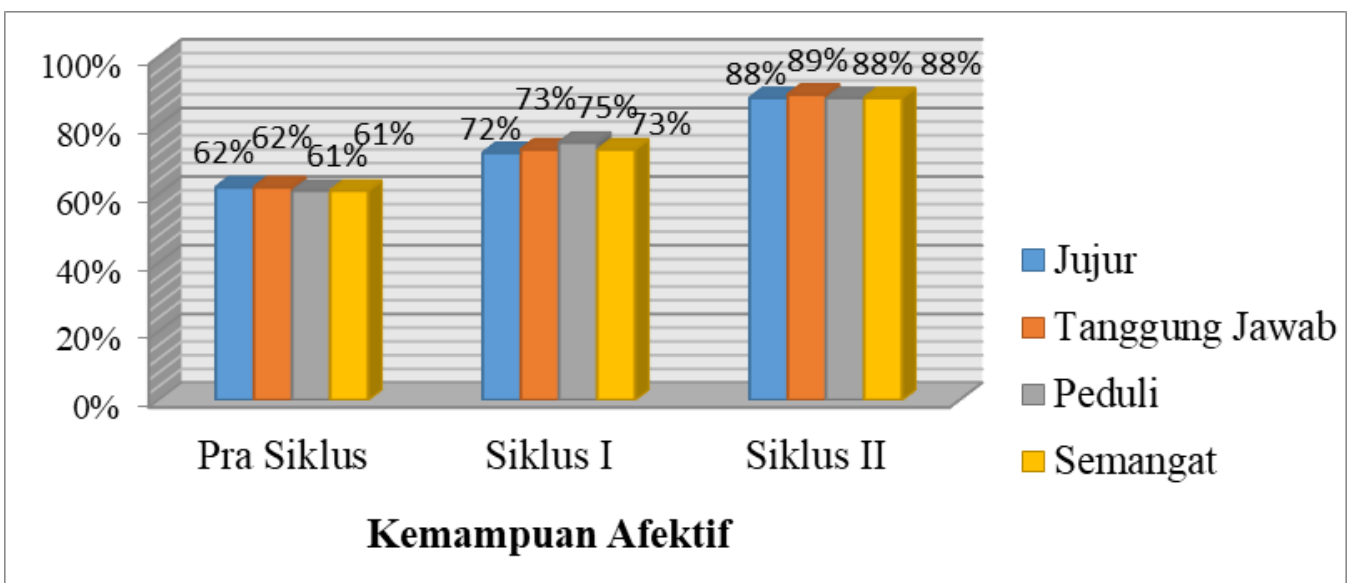

Dapat disimpulkan bahwa terjadi peningkatan dalam penanaman nilai-nilai kejujuran, tanggung jawab, peduli, dan semangat melalui pembelajaran dengan menggunakan $V C T$ menjadi semakin baik dan terjadi peningkatan yang signifikan dari setiap siklusnya. Demikian juga pada penelitian, terdapat peningkatan terhadap kemampuan afektif sisiwa dalam memahami nilai kejujuran, tanggung jawab, peduli, dan semangat pada pembelajaran PKn materi tentang Menaati Peraturan Perundang-undangan yang berlaku di Indonesia.

Berdasarkan hasil penelitian dan analisis teori dapat disimpulkan bahwa model VCT dapat diterapkan pada materi tentang Menaati Peraturan Perundang-undangan yang berlaku di Indonesia yang berdampak pada meningkatnya kemampuan afektif peserta didik kelas $\mathrm{V}$ MI Al-Mubarok Margolinduk Bonang Demak. 
Ali Imron

\section{SIMPULAN}

Berdasarkan hasil Penilitian Tindakan Kelas yang telah dilakukan tentang Peningkatkan Kemampuan Afektif peserta didik Pada Mata Pelajaran Pendidikan Kewarganegaraan $(\mathrm{PKn})$ dengan Model Pembelajaran Value Clarification Technique (VCT) Kelas V MI Al-Mubarok Margolinduk Bonang Demak Tahun Pelajaran 2017/2018", dapat disimpulkan bahwa Pelaksanaan model pembelajaran VCT di kelas V MI Al-Mubarok Margolinduk Bonang Demak terlaksana dengan baik. Dengan penerapan model VCT dapat meningkatkan aktivitas dan kreatifitas siswa dalam proses pembelajaran. Model VCT yang diterapkan pada mata pelajaran Pendidikan Kewarganegaraan (PKn) di kelas V MI Al-Mubarok Margolinduk Bonang Demak dapat meningkatkan kemampuan afektif siswa dalam memahami nilai kejujuran, tanggung jawab, dan peduli. Hal ini dapat dilihat dari lembar penilaian skala sikap setiap siklusnya. Semakin banyak siswa mencapai skor ketuntasan minimal yang ditentukan. Peningkatan ini sesuai dengan target indikator keberhasilan yang telah dirumuskan peneliti. Terbukti dari hasil skala sikap siklus 2 kemampuan afektif siswa dalam memahami nilai kejujuran, tanggung jawab, peduli, dan semangat meningkat "sangat baik" yakni masing-masing mencapai skor sebesar $88 \%$, 89\%, 88\%, dan 88\%. Serta aktivitas siswa melalui penerapan model pembelajaran $V C T$ juga mengalami peningkatan, yang paling menonjol adalah aktivitas di analisis dan presentasi hasil diskusi kelompok. Siswa dulunya pasif menjadi lebih aktif dan bersemangat mengikuti pembelajaran.

\section{DAFTAR PUSTAKA}

Arikunto, Suharsimi. Prosedur Penelitian. Jakarta: PT Rineka Cipta, 2013.

—. Prosedur Penelitian Suatu Pendekatan Praktik, Jakarta: Rineka Cipta, 2010.

Fatturohman, Muhammad. Model-Model Pembelajaran Inovatif. Yogyakarta: Ar-Ruzz Media, 2015.

Gunansyah, Eny Sukmawati dan Ganes, Upaya Meningkatkan Hasil Belajar IPS Melalui Penerapan Model Pembelajaran Value Clarification Technique (VCT), Jurnal Penelitian Pendidikan Guru Sekolah Dasar 2, no. 3, 2014.

Hanbal, Al-Imam Ahmad bin. Musnad. Beirut: Darul Kutub al-Ilmiah, n.d. 
Haris, Fairizah, Penerapan Model Pembelajaran Vct (Value Clarification Technique) Untuk Meningkatkan Kesadaran Nilai Menghargai Jasa Pahlawan Pada Siswa Sekolah Dasar. Jurnal Penelitian Pendidikan Guru Sekolah Dasar 1, no. 2, 2013.

Ichas, S. Ichas Hamid Al-lamri dan Tuti Istianti. Pengembangan Pendidikan Nilai Dalam Pembelajaran Pengetahuan Sosial Di Sekolah Dasar. Jakarta: Dirjendikti, 2006.

Imron, Ali, Peningkatan Hasil Belajar Menggunakan Metode Demonstrasi Pada Bidang Studi Al Qur'an Hadits MI. MAGISTRA 7, no. 1, 2016.

Indarti, Titik. Penelitian Tindakan Kelas (PTK) Dan Penulisan Ilmiah, . Surabaya: FBS UNESA, 2008.

Lickona, Thomas. Educating For Character. Edited by Bumi Aksara. Jakarta, 2013.

Martanti, Fitria, Penanaman Nilai-nilai Kejujuran Melalui Media Kantin Kejujuran di Pondok Pesantren Al-Hikmah Semarang, Jurnal Sosio Dialektika Volume 2, 2017.

Martoni, Andrizal, Helbi Akbar, Penerapan Teknik Mengklarifikasi Nilai (Value Clarification Technique) Untuk Meningkatkan Pemahaman Belajar Siswa Pada Mata Pelajaran Pendidikan Agama Islam, J-PAI: Jurnal Pendidikan Agama Islam 5, no. 2, 2019.

Priansa, Euis Karwati dan Donni Juni. Manajemen Kelas (Classroom Management). Bandung: Alfabeta, 2014.

Ridlwan. Meningkatkan Pengembangan Ranah Afektif Siswa Dalam Pendidikan Agama Islam (PAI) Kelas III Di SD Negeri Sukosewu Kec. Sukosewu Kab. Bojonegoro. Karya Pendidikan 2, no. 3, 2016.

Setiana, Gustin Indra. Penerapan Model Pembelajaran Value Clarification Technique (VCT) Permainan Untuk Meningkatkan Hasil Belajar PKn Pada Siswa Kelas II SD Negeri Kemandungan 3 Kota Tegal'. Semarang: Fakultas Pendidikan, 2012.

Sofyan, Muhammad Nurtanto dan Herminarto, Implementasi Problem-Based Learning Untuk Meningkatkan Hasil Belajar Kognitif, Psikomotor, Dan Afektif Siswa Di Smk. Pendidikan VOKASI 5, no. 3, 2015.

Sugiyono. Metode Penelitian Pendidikan. Bandung: Alfabeta, 2015.

Suryadi, Ace. Pendidikan Indonesia Menuju 2025. Bandung: PT Remaja Rosdakarya, 2014.

Taniredja, Tukiran. Model-Model Pembelajaran Inovatif Dan Efektif. Bandung: Alfabeta, 2015.

Trianto. Mendesain Model Pembelajaran Inovatif-Progresif. Jakarta: Kencana, 2011.

Tukiran Taniredja, Et.all. Model-Model Pembelajaran Inovatif Dan Efektif,. Bandung: 


\section{Ali Imron}

Alfabeta, 2015.

Wuryandani, Fathurrohman dan Wuri. Pembelajaran PKn Di Sekolah Dasar. Yogyakarta: Nuha Litera, 2011.

Page | 107 